\title{
Amino acids profile of loofah gourd Luffa cylindrica (M J Roem) seeds subjected to
} different heat processing methods

${ }^{1,{ }^{*}}$ Onigemo, M. A., ${ }^{2}$ Dairo, F. A. S. and Oso, Y. A. A. ${ }^{3}$

${ }^{\prime}$ Department of Animal Production Technology, Lagos State Polytechnic, Ikorodu, Nigeria

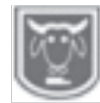

${ }^{2}$ Department of Animal Science, Ekiti State University, Ado-Ekiti, Nigeria

${ }^{3}$ Department of Agricultural Technology, Lagos State Polytechnic, Ikorodu, Nigeria

Abstract Corresponding author: maonigemo@gmail.com;+2348022770999

The major limiting factor to the utilisation of loofah gourd seeds (LGS) as food is its high content of anti-nutrient. Heat processing is one of the process of reducing the concentration of anti-nutrients in food resources which may adversely influence the amino acids contents of such resources. Raw seeds of loofah gourds (RLGS) were toasted (TLGS), boiled (BLGS) and cooked (CGLS) and analysed for the amino acids content. The amino acids score, the essential amino acids score and the predicted (P-PER) of the raw and heat treated RLGS were calculated using standard equations. Results revealed that heat treatment significantly reduced $(P<0.05)$ the essential amino acids, total sulphur containing amino acids and total basic amino acids while significantly $(P<0.05)$ increasing the total amino acids, and total non-essential amino acids. cysteine is the most reduced amino acids and toasting had the highest reduction effect on the amino acids. P-PER of LGS were significantly enhanced by heat processing. Glutamic acid and aspartic acid were the most abundant amino acids while cysteine and methionine were the major limiting amino acids in the raw and processed LGS. In conclusion, heat processing enhances the nutritional potentials of LGS and wet heat processing boiling and cooking are the most preferred processing methods for loofah gourd seed.

Keywords: loofah gourd seeds, toasting, boiling, cooking, amino acids.

\section{Introduction}

Loofah (Luffa cylindrica L.) is a plant that originated from India which produces berry like fruit whose colour at tender stage is green with cucumber-like interior when immature, and yellow at puberty with a network of fibre surrounding at least 30 or more flat black seeds (Sofowora, 1982; Newton, 2006; Oyetayo and Ojo, 2012; Silva et al., 2012). The fruit is harvested before puberty and eaten as vegetables in some part of Asia and Africa and serves as the source of the sponge (Newton, 2006). It is an excellent fruit in nature containing all the essential constituents required for good health of humans (Rahman, 2003). Its kernel contains between $45-51 \%$ oil which composed of mainly oleic and linoleic acids; the seeds have laxative properties due to their high oil content and contains a wide range of secondary metabolites with distinct biological activities that could be useful in the treatment of asthma, sinusitis and fever (Nagao et al., 1991). It is reported to possess antiviral, anti-tumor, antioxidant, anti-inflammatory and immunomodulatory activities (TanninSpitz et al., 2007).

In Nigeria, the plant grows in the wild, abandoned building structures, fences and walls in towns and villages, while in some parts of the country, loofah plants are grown for its sponge which is used to wash dish, human bathing sponge and in traditional medical practice (Dairo et al., 2007; Onigemo et al., 2015). The seeds which are often discarded as waste are leguminous in nature, potentially rich in energy and 


\section{Amino acids profile of loofah gourd Luffa cylindrica (M J Roem)}

protein and could be used as a source of vegetable protein and energy in human and animal diets (Lee and Yoo, 2006; Dairo et al., 2007; Abitogun and Ashogon, 2010). One main criterion in the use of any material as feed ingredients is its nutrient composition and there is dearth of information on the amino acids content of loofah seeds. Also, the types of processing procedure feedstuff are subjected to also influence their nutrient profile and availability (Ajala, 2009). This study was therefore designed to determine the amino acids composition of loofah gourd seed subjected to three heat processing methods so as to confirm its potentials as a source of vegetable protein in livestock diets.

\section{Materials and methods}

Luffa cylindrica (MJ Roem) was harvested during the dry season in the south west, and north central geographical regions of Nigeria. The gourds were harvested when the gourds coat had dried and turned leathery brown. Seeds were removed from the cucumber shaped fruits by breaking the leather colour coating on the gourd to expose the sponge in it. The black hard coated seeds were removed by vigorously agitating. The seeds obtained from the sponge were soaked in fairly hot water at $60^{\circ} \mathrm{C}$ for 12 hours and thereafter dehulled by removing the black seed coat that had been softened by the soaking process. The dehulled seed was then sundried. Foreign materials were removed from the sundried dehulled seeds by winnowing and the thoroughly cleaned seeds were divided into four parts for dry and wet heat processing namely cooking, boiling and toasting. The first part of the clean dried seeds was poured into already boiling water and left for 30 minutes to cook. The water was allowed to cover the seeds and the ratio of water to seeds was $5: 1$ by volume. The cooked seedswere poured into a sieve and allowed to drain properly. The cooked drained seed was then sun dried for three days and labelled cooked loofah gourd seed (CLGS). The second part of the clean dried seed was poured in a jute bag and immersed in hot boiling water and heated for five minutes when the water begins to boil again. The boiled seed was then sun dried for three days and labelled boiled loofah gourd seed (BLGS). The third part of the clean dried seed was roasted for 30 minutes at $100-110^{\circ} \mathrm{C}$ in a gari fryer along with clean fine sand to prevent the seed from getting burnt and to ensure uniform distribution of heat. The seeds and sand mixture were continuously stirred throughout the toasting process using a wooden spatula. The toasted seeds were sieved out of the fine sand and allowed to cool. This was labelled toasted loofah gourd seed (TLGS). The forth part was not exposed to any form of heat treatment and was labelled raw loofah gourd seed (RLGS). The three differently processed seeds as well as the raw seeds were grinded using plate mill and packed in polythene sachets. The amino acids content of loofah gourd seeds were analyzed using Ingos ${ }^{\circledR}$ Automatic Amino Acids Analyzer AAA, 400 PIKRON sro ${ }^{\circledR}$. The amino acid score was determined based on the whole hen's egg as described by Paul et al., (1976). It was calculated by using the ratio of amino acid in the test protein to those in the reference protein for each amino acid. The essential amino acid score was based on the provisional amino acid scoring pattern using the FAO/WHO, (1973) formula: Amino acid score $=$ Amount of amino acid per test protein $[\mathrm{mg} / \mathrm{g}] /$ Amount of amino acid per protein in reference protein $[\mathrm{mg} / \mathrm{g}]$. Predicted protein efficiency ratio (P-PER) was determined using the equations developed by Alsmeyer et al., (1974): $\quad P-P E R=-0.468+0.454$ (Leu) - 
0.105 (Tyr). Data were analyzed using analysis of variance. The means were separated using Duncan Multiple Range Test. All statistical analysis was done using the Assistat-Statistical Assistance 7.7 beta software developed by Silva and Azevedo (2016).

\section{Results and discussion}

The amino acids value of the heat processed LGSM were significantly $(\mathrm{P}<0.05)$ affected by heat treatment except aspartic acid, isoleucine, methionine, alanine, glutamic acid and proline (Table 1).
Cysteine and methionine were the most limiting amino acid. Cysteine ranged between 5.67 - $10.14 \mathrm{mg} / \mathrm{g}$. RLGSM recorded the highest value of $10.14 \mathrm{mg} / \mathrm{g}$ while TLGSM had the lowest $(5.67 \mathrm{mg} / \mathrm{g})$ and similar to those obtained for BLGSM and CLGSM. The values for methionine ranged from $12.25-12.50 \mathrm{mg} / \mathrm{g}$. Glutamic acid and aspartic acid were the most abundant amino acids in the LGSM. Heat processing significantly reduced cysteine, lysine, glycine and arginine content of LGSM with cysteine, arginine and lysine having the trend of RLGSM > BLGSM > CLGSM > TLGSM.

Table 1: Amino acids profile of loofah gourd seeds subjected to different heat processing methods

\begin{tabular}{lccccc}
\hline \multirow{2}{*}{ Amino acids } & \multicolumn{4}{c}{ Methods of processing } & \\
\cline { 2 - 5 } & Raw & Toasting & Boiling & Cooking & SEM \\
\hline Lysine & $41.18^{\mathrm{a}}$ & $39.12^{\mathrm{b}}$ & $39.53^{\mathrm{b}}$ & $39.14^{\mathrm{b}}$ & 0.49 \\
Histidine & 28.38 & 28.66 & 28.52 & 28.63 & 0.06 \\
Arginine & $62.88^{\mathrm{a}}$ & $59.78^{\mathrm{c}}$ & $61.64^{\mathrm{b}}$ & $60.77^{\mathrm{b}}$ & 0.66 \\
Aspartic acid & 95.76 & 94.99 & 95.35 & 95.67 & 0.17 \\
Threonine & $32.13^{\mathrm{ab}}$ & $31.95^{\mathrm{b}}$ & $32.45^{\mathrm{a}}$ & $32.06^{\mathrm{b}}$ & 0.11 \\
Serine & $33.34^{\mathrm{b}}$ & $33.94^{\mathrm{a}}$ & $33.66^{\mathrm{ab}}$ & $33.34^{\mathrm{b}}$ & 0.14 \\
Glutamic acid & 97.31 & 97.31 & 97.31 & 97.31 & 0.00 \\
Proline & 30.98 & 30.98 & 30.98 & 30.98 & 0.00 \\
Glycine & $27.98^{\mathrm{a}}$ & $27.54^{\mathrm{c}}$ & $27.78^{\mathrm{bc}}$ & $27.93^{\mathrm{ab}}$ & 0.10 \\
Alanine & 27.45 & 27.41 & 27.69 & 27.41 & 0.30 \\
Cysteine & $10.14^{\mathrm{a}}$ & $5.67^{\mathrm{b}}$ & $6.59^{\mathrm{b}}$ & $6.29^{\mathrm{b}}$ & 1.01 \\
Valine & $36.88^{\mathrm{b}}$ & $37.62^{\mathrm{a}}$ & $37.09^{\mathrm{b}}$ & $37.24^{\mathrm{ab}}$ & 0.16 \\
Methionine & 12.25 & 12.5 & 12.35 & 12.43 & 0.05 \\
Isoleucine & 32.55 & 32.15 & 31.59 & 32.45 & 0.22 \\
Leucine & $70.88^{\mathrm{c}}$ & $73.06^{\mathrm{a}}$ & $72.23^{\mathrm{b}}$ & $72.65^{\mathrm{ab}}$ & 0.47 \\
Tyrosine & $34.66^{\mathrm{a}}$ & $34.89^{\mathrm{a}}$ & $34.60^{\mathrm{a}}$ & $33.69^{\mathrm{b}}$ & 0.26 \\
Phenylalanine & $43.87^{\mathrm{b}}$ & $43.44^{\mathrm{b}}$ & $44.31^{\mathrm{a}}$ & $44.52^{\mathrm{a}}$ & 0.24 \\
PER & $28.07^{\mathrm{b}}$ & $29.04^{\mathrm{a}}$ & $28.69^{\mathrm{a}}$ & $28.98^{\mathrm{a}}$ & 0.17 \\
\hline
\end{tabular}

$\mathrm{abc} \rightarrow$ Means on the same row with different superscript differ significantly $(\mathrm{P}<0.05)$

Heat processing significantly $(\mathrm{P}<0.05)$ increased the valine and leucine value of treated LGSM above that of RLGSM. The valine content of TLGSM and CLGSM were similar $(\mathrm{P}>0.05)$ but higher than the value for RLGSM. Histidine and methionine content of LGSM increased with heat application. Histidine ranged between $28.38 \mathrm{mg} / \mathrm{g}$ (RLGSM) to 28.66 $\mathrm{mg} / \mathrm{g}$ (TLGSM). Glutamic acid and proline appeared not to be affected by the heat treatment as their values remain unchanged post processing and are the same for the treated LGSM and RLGSM. Alanine values 
were also not influenced by heat treatment and ranges from $27.69 \mathrm{mg} / \mathrm{g}$ for BLGSM to $27.41 \mathrm{mg} / \mathrm{g}$ for TLGSM and CLGSM. Phenylalanine was highest in CLGSM (44.52 $\mathrm{mg} / \mathrm{g})$ and lowest in TLGSM (43.44 $\mathrm{mg} / \mathrm{g})$. Serine had the highest value of 33.94 $\mathrm{mg} / \mathrm{g}$ in TLGSM followed by BLGSM (33.66 $\mathrm{mg} / \mathrm{g}$ ) then CLGSM and RLGSM with the same value of $33.34 \mathrm{mg} / \mathrm{g}$. Tyrosine value was highest in TLGSM (34.89 mg/g) and lowest (33.69 mg/g) in CLGSM and while the highest value of Threonine was recorded in BLGSM (32.45 $\mathrm{mg} / \mathrm{g}$ ) and the lowest in TLGSM (31.95 $\mathrm{mg} / \mathrm{g}$ ). The result of this study showed that loofah gourd seed was rich in amino acids. Also, different heat processing methods significantly affected the amino acid profile of the loofah gourd seed except histidine, aspartic acid, glutamic acid, proline, alanine, methionine and isoleucine. The values of the amino acids observed in this study are comparable to those reported in literature (Aremu et al., 2006; Olaofe et al., 2008; Aremu et al., 2010; Aremu et al., 2011). The most concentrated amino acids were glutamic acid, aspartic acid, leucine and arginine which support the findings of Ogunji et al. (2003); Mubarak (2005); Olaofe et al. (2008) and Dairo et al. (2013) Methionine and cysteine were slightly deficient in LGSM as indicated in the result of the study which conform with the report of other workers (FAO/WHO, 1991; Olaofe et al., 2008). Methionine and cysteine appeared to be generally deficient in legumes and most of the oil-bearing seeds as documented for mung bean (Mubarak, 2005); Mucuna pruriens (Kala and Mohan, 2010) and Mosquito bean (Kathrivel and Kumudha, 2011). Cysteine was significantly decreased by treatment effect. The RLGSM had higher cysteine value than any of the treated LGSM which were similar in values. This might be due to the effect of heat on the amino acids that may have depleted it in the seed as reported by previous workers (Mubarak, 2005; Dairo et $a l ., 2013)$. The lower cysteine value of the processed seeds might be attributed to the action of heat on the amino acids. Van Barneveld et al., (1994 a and b) reported that heating results in the formation of a hydroalanyl residue from cysteine, which is capable of binding the e-amino group of lysine to form lysinoalanine, hence the significant reduction in the lysine value of the treated seed when compared to RLGSM. The limiting methionine and cysteine content of raw and treated loofah gourd seed would require the use of other quality vegetable protein sources such as soybean or groundnut supplementation in order to correct for this deficiency when used in livestock feed. Dairo et al. (2008) has reported a 5\% tolerable inclusion level or raw loofah gourd seed meal in rabbit diet supplemented with other protein source so as to reduce the high cost of protein source. Histidine, serine and valine content increased by the heat treatment with TLGSM having the highest value. This observation agrees with the report of Mubarak (2005) but at variance with that of Dairo et al. (2013) who reported a decreased value due to boiling and cooking. Lysine, glycine, isoleucine and phenylalanine were significantly reduced by heat treatment as compared with RLGSM which agreed with the report of previous workers on mung bean and loofah seeds (Mubarak, 2005; Dairo et al., 2013). Table 2 shows the amino acid score of loofah gourd seeds (LGSM) subjected to different heat processing methods. The treatment significantly $(\mathrm{P}<0.05)$ affected the amino acid score of loofah gourd seeds (LGSM) except serine and glutamic acid. The amino acid score of cysteine, lysine, arginine and aspartic acid were significantly $(\mathrm{P}<0.05)$ reduced below that of RLGSM. The TLGSM value for cysteine 
(25.77) was significantly $(\mathrm{P}<0.05)$ lowered than those of RLGSM, BLGSM and CLGSM with values of 46.09, 29.95 and 28.59 respectively. Arginine value was significantly $(\mathrm{P}<0.05)$ different among LGSM exposed to different heat processing methods. Arginine value was significantly $(\mathrm{P}<0.05)$ lowest in TLGSM (89.22) and followed by CLGSM (90.70), BLGSM (92.00) and RLGSM (93.85) in ascending order. Aspartic value of the LGSM varied significantly $(\mathrm{P}<0.05)$, the values of
RLGSM and CLGSM were similar (P> 0.05 ) and higher than others. In addition, aspartic acid value of CLGSM did not differ significantly $(\mathrm{P}>0.05)$ from BLGSM. Glycine value of RLGSM (75.62), CLGSM (75.49) and BLGSM (75.08) were similar $(\mathrm{P}>0.05)$ but significantly $(\mathrm{P}<0.05)$ higher than TLGSM (74.43). Isoleucine values of RLGSM (46.50), CLGSM (46.36) and TLGSM (45.93) were similar but different significantly $(\mathrm{P}<0.05)$ from what was obtained in BLGSM (45.13).

Table 2: Amino acid score of loofah gourd seeds subjected to different heat processing methods

\begin{tabular}{|c|c|c|c|c|c|}
\hline \multirow{2}{*}{ Amino acids } & \multicolumn{4}{|c|}{ Methods of processing } & \multirow{2}{*}{ SEM } \\
\hline & Raw & Toasting & Boiling & Cooking & \\
\hline Lysine & $60.56^{\mathrm{a}}$ & $57.53^{\mathrm{b}}$ & $58.13^{\mathrm{b}}$ & $57.56^{\mathrm{b}}$ & 0.72 \\
\hline Histidine & $105.11^{\mathrm{b}}$ & $106.15^{\mathrm{a}}$ & $105.63^{\mathrm{ab}}$ & $106.04^{\mathrm{a}}$ & 0.24 \\
\hline Arginine & $93.85^{\mathrm{a}}$ & $89.22^{\mathrm{d}}$ & $92.00^{\mathrm{b}}$ & $90.70^{c}$ & 0.98 \\
\hline Aspartic Acid & $165.10^{\mathrm{a}}$ & $163.78^{\mathrm{c}}$ & $164.40^{\mathrm{bc}}$ & $164.95^{\mathrm{ab}}$ & 0.30 \\
\hline Threonine & $58.42^{\mathrm{b}}$ & $58.09^{\mathrm{b}}$ & $59.00^{\mathrm{a}}$ & $58.29^{\mathrm{b}}$ & 0.20 \\
\hline Serine & 43.30 & 44.08 & 43.71 & 43.30 & 0.19 \\
\hline Glutamic Acid & 79.11 & 79.11 & 79.11 & 79.11 & 0.00 \\
\hline Glycine & $75.62^{\mathrm{a}}$ & $74.43^{b}$ & $75.08^{\mathrm{a}}$ & $75.49^{\mathrm{a}}$ & 0.27 \\
\hline Cysteine & $46.09^{\mathrm{a}}$ & $25.77^{\mathrm{c}}$ & $29.95^{\mathrm{b}}$ & $28.59^{b}$ & 4.58 \\
\hline Valine & $44.98^{b}$ & $45.88^{\mathrm{a}}$ & $45.23^{\mathrm{b}}$ & $45.41^{\mathrm{ab}}$ & 0.19 \\
\hline Methionine & $37.12^{b}$ & $37.88^{\mathrm{a}}$ & $37.42^{\mathrm{ab}}$ & $37.67^{\mathrm{a}}$ & 0.16 \\
\hline Isoleucine & $46.50^{\mathrm{a}}$ & $45.93^{\mathrm{a}}$ & $45.13^{\mathrm{b}}$ & $46.36^{\mathrm{a}}$ & 0.31 \\
\hline Leucine & $83.39^{c}$ & $85.95^{\mathrm{a}}$ & $84.98^{b}$ & $85.47^{\mathrm{ab}}$ & 0.56 \\
\hline Tyrosine & $75.35^{\mathrm{a}}$ & $75.85^{\mathrm{a}}$ & $75.22^{\mathrm{a}}$ & $73.24^{\mathrm{b}}$ & 0.57 \\
\hline Phenylalanine & $81.24^{\mathrm{b}}$ & $80.44^{\mathrm{c}}$ & $82.06^{\mathrm{a}}$ & $82.44^{\mathrm{a}}$ & 0.45 \\
\hline
\end{tabular}

$\mathrm{abc} \rightarrow$ Means on the same row with different supersdifffet significantly $(\mathrm{P}<0.05)$.

Histidine score values in RLGSM (105.11) and BLGSM (105.63) were similar (P> $0.05)$ but significantly $(\mathrm{P}<0.05)$ lower than those of TLGSM (106.15) and CLGSM (106.04) which were also similar ( $\mathrm{P}>0.05)$. The highest valine was recorded in TLGSM (45.88) which was similar to that CLGSM (45.41), but differ significantly $(\mathrm{P}<0.05)$ from those of BLGSM (45.23) and RLGSM (44.98) which were also similar $(\mathrm{P}>0.05)$. The score of methionine was significantly $(\mathrm{P}<0.05)$ highest in TLGSM (37.88) and lowest in RLGSM. The result showed that TLGSM significantly $(\mathrm{P}<$ 0.05 ) recorded the highest value for methionine (37.88), leucine (85.95) and Tyrosine (75.85) and the lowest values were recorded in RLGSM for both methionine (37.12) and leucine (83.39) while CLGSM had the lowest tyrosine value. BLGSM had significantly $(\mathrm{P}<0.05)$ higher threonine score those others which were similar in their score. Phenylalanine scores were similar in CLGSM (82.44) and BLGSM (82.06) but are significantly $(\mathrm{P}<0.05)$ different from others while TLGSM (80.44) 
had the lowest score. The amino acid score of raw and heat-treated loofah gourd seeds significantly differ $(\mathrm{P}<0.05)$ from one another except with respect to serine and glutamic acid. Methionine scores were similar in treated LGSM and lowest in RLGSM. However, cysteine score was found to be greatly reduced by heat treatment hence, could be regarded as one limiting amino acid in treated LGSM. This result is in line with the findings of earlier workers that cysteine and methionine are the limiting amino acids in seeds of tropical plants (Kala and Mohan, 2010; Kathirvel and Kumudha, 2011; Dairo, et al., 2013; Galili and Amir, 2013). However, Olaofe et al. (2008) reported lysine as the limiting amino acid in a LGSM kernel. Lysine score was reduced by the heat treatment and this agrees with the findings of Dairo et al. (2013) who reported a similar result in dehulled LGSM exposed to cooking and boiling. Therefore, the use of heat-treated loofah gourd seed will require other quality protein sources to supplement the deficiencies. However, valine and leucine scored higher for heat treated loofah gourd seed when compared to RLGSM. Dairo et al. (2013) reported reduction in valine and leucine score as a result of boiling and cooking. Aspartic acid scored the highest among the amino acid found in loofah gourd seed followed by histidine. Heat treatment significantly reduced the aspartic acid score whereas, histidine scores of the loofah gourds seed was significantly increased. Dairo et al. (2013) also reported increased histidine score as a result of boiling. Heat treatment significantly reduced arginine and glycine score of treated loofah gourd seed with toasting having the lowest values. Table 3 shows the essential amino acid pattern of loofah gourd seeds (LGSM) subjected to different heat application methods. Heat application significantly $(\mathrm{P}<0.05)$ influenced the amino acids pattern in LGSM. The RLGSM recorded the highest values for the sulphur containing amino acids, essential amino acids (EEA) with or without histidine, total acidic amino acids (TAA), total basic amino acids (TBA), and percentage EEA with or without histidine. The EEA values with or without histidine were similar $(\mathrm{P}>0.05)$ in the treated LGSM. However, the predicted PER was lower in RLGSM (28.07) than the treated LGSM.

Table 3: Essential amino acid pattern of loofah gourd seeds subjected to different heat processing methods

\begin{tabular}{lccccc}
\hline \multirow{2}{*}{ Variables } & \multicolumn{4}{c}{ Methods of processing } \\
\cline { 2 - 5 } & Raw & Toasting & Boiling & Cooking & SEM \\
\hline Total aromatic amino acids & $78.53^{\mathrm{ab}}$ & $78.33^{\mathrm{b}}$ & $78.91^{\mathrm{a}}$ & $78.21^{\mathrm{b}}$ & 0.15 \\
Total sulphur containing & $22.39^{\mathrm{a}}$ & $18.17^{\mathrm{b}}$ & $18.94^{\mathrm{b}}$ & $18.72^{\mathrm{b}}$ & 0.96 \\
Total essential amino acids with histidine & $342.92^{\mathrm{a}}$ & $339.06^{\mathrm{b}}$ & $339.26^{\mathrm{b}}$ & $339.10^{\mathrm{b}}$ & 0.95 \\
Total essential amino acids & $314.54^{\mathrm{a}}$ & $310.40^{\mathrm{b}}$ & $310.74^{\mathrm{b}}$ & $310.47^{\mathrm{b}}$ & 1.00 \\
Total non-essential amino acids & $404.08^{\mathrm{b}}$ & $464.22^{\mathrm{a}}$ & $465.63^{\mathrm{a}}$ & $464.66^{\mathrm{a}}$ & 15.19 \\
Total amino acid & $718.62^{\mathrm{b}}$ & $774.62^{\mathrm{b}}$ & $776.37^{\mathrm{a}}$ & $775.13^{\mathrm{a}}$ & 14.19 \\
Total aliphatic amino acids & $226.72^{\mathrm{b}}$ & $228.76^{\mathrm{a}}$ & $227.36^{\mathrm{b}}$ & $228.66^{\mathrm{a}}$ & 0.50 \\
Total acidic amino acids & $193.07^{\mathrm{a}}$ & $192.3^{\mathrm{b}}$ & $192.66^{\mathrm{ab}}$ & $192.98^{\mathrm{ab}}$ & 0.17 \\
Total basic amino acids & $132.44^{\mathrm{a}}$ & $127.56^{\mathrm{c}}$ & $129.69^{\mathrm{b}}$ & $128.54^{\mathrm{bc}}$ & 1.05 \\
\%Total essential amino acid & $43.77^{\mathrm{a}}$ & $40.07^{\mathrm{b}}$ & $40.02^{\mathrm{b}}$ & $40.05^{\mathrm{b}}$ & 0.93 \\
\%Total essential amino acid with histidine & $47.72^{\mathrm{a}}$ & $43.77^{\mathrm{b}}$ & $43.70^{\mathrm{b}}$ & $43.75^{\mathrm{b}}$ & 1.00 \\
\hline abc $\rightarrow$ Means on the same row with different superscript differ & significantly $(\mathrm{P}<0.05)$ & &
\end{tabular}


Heat processing significantly reduced the essential amino acid in loofah gourd seed when compared with the RLGSM. Deshpande et al. (1982) stated that nutritive value of a protein depends primarily on the capacity to satisfy the needs for nitrogen and essential amino acids. Though the values obtained are lower than what has been reported for other legumes like soybean (Kuri et al., 1991), pigeon pea (Nwokolo, 1987) and Cajanus cajan (Olaofe et al., 1993) it however compared well with what was reported for pumpkin seed, Leganaria sciceraria, and Luffa cylindrica. (Aisegbu, 1987; Olaofe et al., 2009; Dairo et al., 2013). Therefore, the nutritive value of the processed seeds is still capable of providing the needed essential amino acids as the values obtained in this study are above the recommended values for leucine (19-44), valine (13-25), threonine (9-28), phenylalanine and tyrosine (19-22) for adult and children (1012 years), respectively (FAO/WHO, 1991).

\section{Conclusion}

Heat processing enhanced the predicted protein efficiency ratio but reduced the value and score of essential amino acids. Toasting had the highest reduction effect on total sulphur containing amino acids, total essential amino acids with histidine, total essential amino acids, total aromatic amino acid and total basic amino acids and the lowest reduction effect on total aliphatic amino acids. Consequently, boiling and cooking may be preferred for processing loofah gourd seed for a better nutrient content.

\section{References}

Abitogun, A. S. and Ashogbon, A. O. 2010. Nutritional Assessment and Chemical Composition of Raw and Defatted Luffa cylindrica Seed Flour. Ethnobotanical Leaflets 14:
225-35.

Aisegbu, J. E. 1987. Some biochemical evaluation of fluted pumpkin seed. J. Sci. Food Agric., 40: 151-155.

Ajala, L. 2009. The Effect of Boiling on the Nutrients and Anti-Nutrients in Two non-Conventional Vegetables. Pakistan Journal of Nutrition 8 (9): 1430-1433, 2009.

Alsmeyer, R. H., Cunningham, A. E. and Happich, M. L. 1974. Equations to predict PER from amino acid analysis. Food Technology. 28: 3438.

Aremu, M. O, Olaofe, O, Akintayo, E. T. 2006. A comparative study on the chemical and amino acid composition of some Nigerian under-utilized legume flours. Pak. J. Nutr., 5(1): 34 - 38 .

Aremu, M. O. Olaofe, O. Okiribiti B. Y. 2008. Chemical Evaluation of the Nutritive Value of Smooth luffa (Luffa cylindrica) Seed's Kernell. Electronic Journal of Environmental and Agricultural Food Chemistry, 7(10), 34443452.

Aremu, M. O., Nweze, C. C. and Alade, P. 2011. Evaluation of Protein and Amino Acid Composition of Selected Spices Grown in the Middle Belt Region of Nigeria. Pakistan Journal of Nutrition 10 (10): 991-995

Aremu, M. O., Olaofe, O., Basu, S. K., Abdulazeez, G. and Acharya, S. N. 2010. Processed cranberry bean (Phaseolus coccineus L.) seed flour for the African diet. Can. J. Plant Sci., 90: 719-728.

Dairo, F. A. S., Aye, P. A. and Oluwasola, T. A. 2007. Some functional properties of loofah gourd (Luffa cylindrica L., M. J. Roem) seed. Journal: Food, Agriculture and 
Environment (JFAE) Vol. 5, Issue 1, pages 97-101.

Dairo, F. A. S., Fasuyi, O. A. Adeyeye, E. I. and Aye, P. A. 2013. Effect of heat on loofah gourd seeds chemical composition and fatty acids of raw seeds. Int. J. Biol. Chem.Sci.7(3): 1289-1297.

Deshpande, S. S. Sathe, S. K. Salunkhe, D. K. and Cornforth, D. P. 1982. Effect of dehulling on phytic acid, polyphenols and enzyme inhibitors of dry beans (Phaseolus vulgaris L.). J. Food Sci, 47:1846-1850.

FAO/WHO. 1973: Energy and protein requirements. Technical Report Series No.522. WHO. Geneva, Switzerland, 61-73.

FAO/WHO. 1991. FAO/WHO, Protein quality evaluation, Report of joint FAO/WHO Expert consultation, FAO Food and Nutrition No 51, Rome, Italy.

Galili, G., and Amir, R. 2013. Fortifying plants with essential amino acids lysine and methionine to improve nutritional quality. Plant Biotechnology Journal 11: 211222.

Kala, B. K. and Mohan, V. R. 2010. Chemical Composition and Nutritional Evaluation of Lesser Known Pulses of the Genus, Mucuna. Advances in Bioresearch, 1(2):105-116.

Kathirvel, P. and Kumudha, P. 2011. Chemical composition of Prosopis juliflora (sw.) DC (mosquito bean). International Journal of Applied Biology and Pharmaceutical Technology Volume: 2: Issue-4: Pg: 199-209.

Kuri, E. Y., Rao, K. S., Kaluwi, C., Jones, G. P., and Rivett, D. E. 1991. Chemical composition of Momodica charantis L. Fruits. J.
Agric. and Food Chem., 39: 1762-1763.

Lee, S, and Yoo, J.G. 2006. (WO/2006/019205) method for preparing transformed luffa cylindrica Roem (World Intellectual property organization) http://www.wipo.int/pctdb/en/wo.j sp? IA $=$ KR2004002745andDISPL $A Y=$ STATUS.

Mubarak, A. E. 2005. Nutritional composition and antinutritional factors of mung bean seeds (Phaseolus aureus) as a<ected by some home traditional processes. Food Chemistry 89 (4) pg. $\begin{array}{lllllll}4 & 8 & 9 & - & 4 & 9 & 5\end{array}$. http://www.sciencedirect.com/scie nce/article/pii/S03088146040003 30

Nagao, T., Lanaka, R., Iwase, Y., Hanazone, H. and Okabe, $H$. 1991. Studies on the constituents of Luffa acutangula. Roxb. Clinical Pharmacology Bulletin, 39:599606.

Newton, A. 2006. More On How To Grow A Luffa. Green Living, How To, www.groovygreen.com/groove/fip $=71$

Nwokolo, E. 1987. Nutritional evaluation of pigeon pea meal. Plant Food Hum. Nutr., 37: 283-90.

Ogunji, J. O.; Wirth, M.; Osuigwe, D. I. 2003. Nutrient Composition of Some Tropical Legumes Capable of Substituting Fish meal in Fish diets. J. Agric. Rural Dev. Trop. Subtrop. (Der Tropenlandwirt), 104 (2): 143-148.

Olaofe, B. Y., Okiribit, T. and Aremu, M. O. 2008. Chemical Evaluation of nutritive value of smooth Luffa (Luffa cylindrica) seed kernel, EJEAFChe. 7 (10), 3444-3452.

Olaofe, O, Faleye, F. J., Adeniji, A. A., 
and Akinsola, A. F. 2009. Amino acid and mineral compositions and proximate analysis of Chinese bottle, Lagenaria sciceraria. Electronic J. Eviron. Agric. and Fd. Chem., 8(7): 534-543.

Olaofe, O., Umar, Y. O., Adediran, G. O. 1993. The Effect of Nematocides on the Nutritive Value and Functional Properties of Cowpea seeds (Vigna unguicalata L. walp) Food Chem., 46(4): 337-342.

Onigemo, M.A. Agbalaya, K. and Tijani, L. A., 2015. Response of broiler chickens fed diets containing loofah gourd seed meal. Nigeria Journal of Animal Production. 42(2); 72-79.

Oyetayo, F. C. and Ojo, B. A. 2012. Food Value and Antinutrients composition of Luffa cylindrica seed flour. America Journal of Biochemistry 2(6): 98-103

Paul, A. A., Southgate, D. A. T. and Russel, J., 1976. First Supplement to McCance and Widdowsons's the Composition of Foods. Her Majesty's Stationery Office, London.

Rahman, A. S. H. 2003. Bottle gourd (Lagenaria siceraria): a vegetable for good health. Natural Product Radiance, 2, 249-250

Silva, F. de A. S. e. and Azevedo, C. A. V. de., 2016. The Assistat Software Version 7.7 and its use in the analysis of experimental data. African Journal of Agricultural Research. Vol. 11(39), pp. 37333740 .

D O I : 10.5897/AJAR2016.11522
Silva, M. W. K. P., Ranil, R. H. G. and Fonseka, R. M. 2012. Luffa cylindrica (L.) M. Roemer (Sponge Gourd-Niyanwetakolu): An Emerging High Potential Underutilized Cucurbit Tropical Agricultural Research Vol. 23 (2): $186-191$.

Sofowora, A. 1982. Medicine Plants and Traditional Medicine in Africa. Ibadan: Spectrum Books Ltd; pp. 90.

Tannin-Spitz, T., Bergman, M., and Grossman, S. 2007. Cucurbita cinglucosides: Antioxidant and free-radical scavenging activities. Biochemical and Biophysical Research Communications, 364, pp.181- 186.

Van Barneveld, R. J., Batterham, E. S. and Norton, B. W. 1994a. The Effect of Heat on amino acids for growing pigs. 1. A Comparison of Ileal and Faecal Digestibilities of Amino Acids in Raw and Heat Treated Field Peas. (Pisum sativum cultivar Dundale). Br. J. Nutr. 72:243-256.

Van Barneveld, R. J., Batterham, E. S. and Norton, B. W. 1994b. The Effect of Heat on amino acids for growing pigs. 2. Utilization of Ileal Digestible lysine from Heat Treated Field Peas. (Pisum sativum cultivar Dundale). Br. J. Nutr. 72: 221-224.

Received: $7^{\text {th }}$ November, 2019 Accepted: $23^{\text {rd }}$ February, 2020 